Marshalltown has increased her population to 5,000 inhabitants. Two railroads give her good facilities for trade; a splendid water power in the Iowa river enbanees her manufacturing abilities; the densely populated country around makes her one of the best depots for trade in Central Iowa. Marshalltown has many enterprising citizens, among them Hon. Delano'Smith, Hon. T.'Brown, B. 'Clark, esq., Dr.'McBride, and J. D. McCord, who are public-spirited men, and have accomplished a great deal for her present prosperity.

Marshall county is one of the central counties in Iowa, and is divided into eighteen townships. It is twenty-four miles square, and contains 368,640 acres of magnificent land, with scarcely a foot that cannot be cultivated, excepting where there is running water. With these advantages she presents a prize to every farmer coming from the east. Marshalltown has seven churches, factories, mills, splendid residences, and the machine shops are soon to be erected for the Central railroad. With these few statistics, we close our very imperfect sketch of Marshall county.

\title{
A FOUL MURDER AND NOBODY KILLED.
}

BY E. W. EASTMAN, ELDORA, IOWA.

THERe has been and now is in Iowa, and in fact in most new states, much opposition to the old system of grand juries, and also to some of the long established rules of evidence in criminal trials. Frontier people are active and impulsive. They think quick, judge quick, and contract quick or not at all. They are here to-day and to-morrow they are westward, ho! with the star of empire. Hence, in legal tribunals, they dislike the slow, formal process of a grand jury, and technical rules of evidence. They want to try the case while the fever is up, and upon such evidence as appears to them to be good, 
and then be at something else. With them, a confession is better than the testimony of an eye-witness.

These forms were of slow growth, and established for personal protection in the long struggle between tyrannical government and impulsive barbarism on the one hand, and individual protection on the other. Cases frequently occur which prore that these formalities are as necessary now for individual protection as when first established. In case of trial for murder, in addition to the grand jury process of first finding a bill of indictment, it has been a long established rule of evidence, that the prosecution must prove that the human being charged to have been killed is dead. This fact can be proved only in two ways, - first, by some one who knows the fact; or, second, by the confession of the accused. Iupulse wants nothing better than a full, clear confession. It is then ready to abandon the slow graild jury work, or any other very formal trial, and-proceed at once to prononnce sentence. And yet this evidence is very unsafe, and really insufficient, to establish the fact that the missing person is dead. The old technicalities of an indictment, and of specific proof, were not adopted withont a reason, and that reason is as frequent to-day as when first adopted.

In the fall of 1848 , a man by the name of Nisely came to my office in Oskaloosa, in this state, and stated to me that he was from Missouri, and had some two or three bushels of apple seeds, and was desirous of starting a nursery, and desired my assistance to procure suitable gronnd. He appeared rather timid, was rather visionary and eccentric, and withal, not very intellectual. While I was trying to arrange for him, he put out and left me to finish the matter up alone. I next heard from him in Jasper county, where he had taken a "claim," and was putting out his seeds in the vicinity of a family of "Hamlins, a father and three grown-up sons. This was in the days of "claims," and Hamlin had a claim and improvement on a half section. I might as well here explain, that by the then statutes of Iowa, a man could take possession of a piece of government land, and improve it, and live on it, 
and hold an interest in the land equal to the value of his improvements. This possession was called a "claim."

Visely boarded part of the time with the'Hamlins, and changed work with them at times. A little "unpleasantness" sprung up between one of the young Hamlins and Nisely, in which some pugilistic demonstration was made by Hamlin, wherempon Nisely left them and went to board at another place. The next Sunday the parties met again, and some unpleasant words passed. Nisely was seen by some persons conversing with the Hamlins. The next day Nisely was missing. Some few days after this, John 'Hamlin, the youngest boy, aged about seventeen years, and the one who had quarreled with Nisely, was seen with Nisely's hat on, and snon after was seen wearing Nisely's coat. Some inquiry was made abont Nisely, and no satisfactory account given by the Hamlins. Perhaps it will be as well to hear say that the Hamlins were beginning, by the three or four families then residing in that part of the county, to be considered rather rough specimens of humanity, and, like an egg in hot water, fast growing harder.

It was soon whispered about among the fifteen or twenty families then in the county, that Nisely had been foully dealt with. In fact, suspicion said Nisely had been inurdered, and John Hamlin was wearing the murdered man's clothes. John was arrested, and, not giving a satisfactory acconnt of the whereabouts of Nisely, or how he came by Nisely's clothes, he was committed to the jail at Oskaloosa. The jail was in the first story of the building, and was not enclosed. The windows were grates without glass, through which persons could converse with the prisoners at all times of day and night.

The excitement increased and spread to the adjoining counties, and people gathered in abont the premises of the Hamlins, and took connsel together. They said to the Hamlins, in language which conld not be misunderstood by frontier people, "Where is Nisely?" It meant, produce him, or speedy justice is right here. They could not evade the ques- 
tion nor quit the county. And, knowing well that frontier people could not be trifled with, they made a clean breast of the whole matter, and confessed that they had murdered Nisely on the fatal Sunday night of his exit.

John was thirty-five miles away in jail. But in the meantime he was interviewed by night through the jail windows, and he also confessed the murder of Nisely, and it was said without knowing that the others had confessed.

Upon these confessions the other three Hamlins were arrested; and a Mr. Smith, who also was beginning a nursery near by, and was supposed to have some interest in getting Nisely out of the way, was also arrested. A messenger was sent to Oskaloosa for me to go up to Newton and defend the Hamlins. The word got to me some time the third day after the arrest. I got off in a short time. Just as I was starting, Mr. Perkins came to me and said he had a pair of duelling pistols lent up at Newton, and desired me to bring them down. On my way up, just before I got to Newton, I met a man with the pistols, going to carry them home, and he desired me to take them, which I did. They were ugly customers, about ten inches long, rifled-barrel bruisers, fixed with a hook to hang upon the waistbund, so as to carry the muzzle down inside the pants and the butt under the rest. We discharged the loads and I hung them in. It was the first and only time I ever carried concealed weapons; and, in fact, these were not concealed, for the heavy, dangling things pulled my pants down so as to leave what a sailor would call a wale streak, two inches wide, between iny pants and vest, across which the two barrels extended. It felt very comical, but I suppose it looked brave in those days.

On arriving in Newton, I found the senior Hamlin nominally in the custody of one Josiah Dooly, high sheriff of Jasper county, but really in the custody,- or rather at the disposal, - of the people there assembled from the adjoining counties. The first words of Mr. Hamlin to me were, "I am glad to see you. I will give you my 'claim' and all that I have if you will only save my life. I am willing to go to prison and 
work faithfully all my life, but I don't want to be hanged.' Seeing he was a little nervous, I replied, "You are not in a condition, now, Mr.'Hamlin, to make a contract. I want first to talk about the case." Several persons crowded up to hear. "Ob," he said, "I am guilty as hell, but I don't want to be hanged." I presently got him aside from the people, and said to him, "Where is Nisely now?" He replied, "I don't know ; the boys put the body out of the way." Then turning his head a little and pulling down his collar, he said, "See my neck. They have been hanging me to make me tell where the body is,- - but I don't know." His neck was somewhat lacerated, and badly swollen, and his head somewhat canted to the left shoulder.

I spoke with Mr.'Smith, and was informed that he had been discharged by the justice, but had not got leave of absence from the people. I inquired for the two young Hamlins, and then learned that the body of Nisely was still missing, - that the Hamlins, after making the confession of the murder, had given very different and contradictory accounts of the disposition made of the body. One account located it in one of Hamlin's stock wells, then out of use, with some rubbish over it; another, in a swampy marsh in Skunk Bottom; another account was that it had been burned on a large sand-bar in Skunk river, and the charred remains raked into the water. Parties were then out with the young Hamlin in search of the body.

The body not having been found in any of the places named, the rope and the lash were both brought in to assist in the search. Nathaniel had been hanged by his thumbs till both were pulled out of place, and the lash applied to his back till the hot blood coursed down over his heels to the ground. The old man had been strung up by the neck till he became willing to give me all he had to save him from a second introduction to the horrors of again using tight hemp for a neck-tie.

I went to the justice's office to examine the papers and prepare for the trial of the three Hamlins. I was quite 
coolly informed that it was no nse to see the papers. "We thought it best to try the case without any lawyers, and we tried the case directly after you were sent for; and I have found them guilty and ordered them to 'Oskaloosa jail. But the sheriff is keeping them to make out some more evidence against them."

I then called Mr. Hamin a little to one side on the prairie, and was conversing with him when $\mathrm{Mr}$. Sheriff ${ }^{V}$ Dooly rather nervously stepped up and said, "See here, Mister, I reckon I have a right to know what you two men are saying." I replied, "I 'reckon' it is none of your business what we are saying. But I was saying to $\mathrm{Mr}$. Hamlin that I would have you in the state prison before three month for lynching him." "Why," said he, with a stare of apparent surprise, "do yon reckon I am liable?" "I know you are, sir; and if you do not hurry off in quick time with these men to jail, I will have you arrested as soon as I can make out the papers. You are high sheriff of Jasper county, and it is your duty to protect these men at the risk of your life. State's prison is hungry for you now, sir." By this time several people had gathered round to hear what was being said. Dooly looked at me first up and then down, and then turned away. The Hamlins were soon after on the road to Oskaloosa jail. I afterwards learned from Dooly that on my first arrival there, those empty, innocent pistols had been olserved through the open streak between vest and pants, and upon a little discussion it had been decided that they meant business, an idea which had never occurred to me, and was why they concluded best to take the Hamlins to jail.

The district court was soon after in session in Oskaloosa, and Henry ${ }^{\vee}$ Temple, an attorney in Oskaloosa, and I took all the Harnlins out of jail on habeas corpus, and had them all discharged, because there was no legal evidence that Nisely ${ }^{v}$ was dead, or, as the law calls it, there was no corpus delicti; the confession by the Hamlins of the killing not being competent to prove that Nisely was dead.

It afterwards turned ont that Nisely, through fear of some 
physical harm, had absconded in the night, and abandoned his claim and nursery, and had left some of his clothing. The Hamlins had no knowledge whatever of his intention to leave or where he had gone. But finding him missing, they had appropriated his clothing and made some demonstration towards taking his claim.

No one could account for the confession of the murder by the Hamlins, and especially by the one in jail. Those out of jail did not retract their confession to me, as their connsel, till several days after first seeing them. Had the grand jury system been abolished, and these men hastily tried on the evidence of their own confessions, they would all have been punished for the murder. These confessions were somewhat of a kin to the Salem witchcraft confessions - those who made them eould not account for doing it.

In conclusion, I may as well here add, that the Hamlins afterwards cheated me out of my fees. The moral to this is, that when a lawyer has a chance to secure a good fee from a slippery client, his better way is to do it at once, and work up his case afterwards.

\title{
RECOLLEOTIONS OF THE EARLY SETTLEMENT OF NORTH- WESTERN IOWA,
}

BY N. LEVERING, GREENWOOD, MO.

(Continued from page 523.)

\begin{abstract}
ON the 13th day of October, 1856, I. T. Martin, Braden ${ }^{\vee}$ Videto, J. McGill, and others, from Harbor Creek, Pa., arrived at Sioux City. They were all active, energetic, and intelligent young vien, who came to the north-west to seek homes and carve out fortunes. They remained in Sioux City during the winter. While there, Mr. Martin and C. Throop erected a store house in Pacific City, a town on the Nebraska
\end{abstract}


Copyright of Annals of Iowa is the property of State of Iowa, by \& through the State Historical Society of Iowa and its content may not be copied or emailed to multiple sites or posted to a listserv without the copyright holder's express written permission. However, users may print, download, or email articles for individual use. 